\title{
ERP Skills - A lifelong learning achievement
}

\author{
S. Sankaranarayanan, Jayshree Suresh
}

\begin{abstract}
Skill Development efforts across the country have been in high demand. India has advantage of having more youth population averaging from age of 25 to 40 years, but there is a surge on the quantum of them having good technical and employability skills. Skill development programs are required to bring their inner capabilities to knowledge and train them with good technical tools. Skill development is not a onetime process and it has to be a continuous process to upgrade oneself to the latest development in technologies. Skill development gives the economic growth of the individual and the nation. Skill development should be envisaged as a life investment. This paper deals with the skill development aspects in the area of ERP and it needs.
\end{abstract}

Index Terms: Enterprise resource planning, Skill development, Lifelong learning

\section{INTRODUCTION}

ERP skills represents a combination of technical skills and business skills. Any successful ERP consultant should have the vast understanding of business requirement and has the ability to articulate the business understanding to ERP functionality. The success as an ERP Consultant and the growth in ERP Career depends on how the market needs are understood and the importance business criticalities. This article highlights some of the key skills required for and ERP professional and that is the need of the industry. It will explore these skills further to provide you with the areas to acquire these skills or improve upon your competencies and expertise levels.

The ERP resources should focus on the results arising from the implementation, and consult on areas where there is a need to deliver value to the customer. Till the time the benefits of the ERP is achieved it is continuously required to train all the stake holders involved in implementation, and produce the value for the cost. There should not be any barrier in the efforts invested in training, to achieve the growth and success.

\section{LITERATURE REVIEW}

ERP systems are aimed to provide data points to the top management for decision making. It provides a wide range of functionalities that can be adopted by the organization, and streamline their business process. Customization should be kept at minimal, as it will incur additional cost for implementation and upgrade [1]. Users should be a given a formal education of ERP which comprises of technical, business, managerial, and interpersonal skills. [2]. ERP system vendors have designed to provide a learning

Revised Manuscript Received on July 05, 2019

S. Sankaranarayanan, Faculty of Management, SRM Institute of Science and Technology, Kattankulathur. Chennai. framework for the communities and encourages them to be included in the curriculum. ERP should not be seen only as a technology implementation, as it has to be bundled with the required training on the skills required to implement and operate them [3].

\section{ERP SKILLS AND IMPLEMENTATION}

ERP has its underlying foundations from MRP and in enhancing quality. Before ERP frameworks were introduced, organizations used MRP II frameworks and other dissimilar frameworks that were not connected consistently.

In this way, all the process of an organization was not synchronized and it resulted in flaws and lack of information. To this point, an ERP framework envelops the majority of the strategic operations of an organization the majority of the internal and external domain users in a synchronized mode of operation.

With the introduction of streamlined process of the organization by introducing the ERP, there emerged a need for the truly skilled personnel in the organization composed themselves into organizations with a specific end goal to protect and advance quality among society individuals. All through this process the quality procedures were produced and moved toward the end and end solution and provided an aggregate quality administration.

There are advantages of incorporating the hands-on ERP practices in an implementation strategy. Hands-on experiential learning gets the trainees effectively associated with the learning procedure. By finishing hands-on ERP exercises, understudies can create specialized abilities as well as better comprehend ERP frameworks and business process mix. Consolidating hands-on ERP practices in ERP after the addresses on big business frameworks is by all accounts a successful instructing approach that enables business understudies to gain strong ERP information, business process learning, and ERP abilities. In this way it is underlined on the significance of joining hands-on ERP practices in the instructing of ERP frameworks.

Taking everything into account, for the two understudies and speakers/mentors, the combination of various ERP frameworks in the educational programs offers a decent chance to pick up a more profound understanding into ERP frameworks and broaden their insight about an assortment of ERP frameworks.

An ERP training program offers a succession of courses that furnishes lucid and thorough substance lined up with testing scholastic models and significant specialized learning and aptitudes expected to get ready for facilitate training and vocations, for example, an ERP pro, ERP engineer, ERP interface expert, ERP chairman, ERP database authority, ERP creator, or ERP organizer in the Information Technology profession bunch; gives

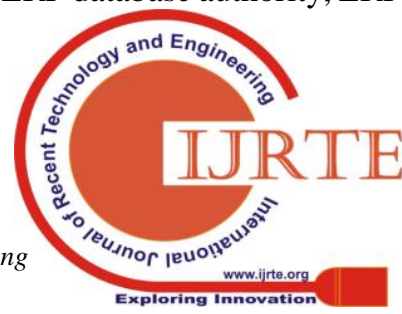


specialized ability capability, and incorporates competency-based connected discovering that adds to the scholarly information, higher-arrange thinking and critical thinking aptitudes, work states of mind, general employability abilities, specialized abilities, and occupation-particular aptitudes, and information of all parts of the Information Technology profession group.

The success of an ERP implementation highly depends on the extent to which the organization plans for the training the users on the ERP at all the stages of the project. The continual success of the ERP requires repeated training and up skilling the new functionalities that are incorporated in the system. There should be a continuous evaluation of the team on the skills they have acquired and encourage them to participate in the training programs.

On comparing the old manual data processes methods, ERP systems' provide a drastic improved capabilities on the data processing. It is made possible because the underlying processes used to develop the data are drastically improved, so there are fewer errors and omissions. Mostly, ERP tools eliminate human input, which accounts to most errors occurring in decision making. As a result, ERP implementation can give the confidence, integrity and reliability of the organization data, which enables a faster and accurate crucial business decisions.

\section{ADVANTAGES OF ERP SKILL}

ERP system can minimize and streamline the day to day tasks, organizing the work location and providing an ideal opportunity to do things that really create satisfaction.

This age favors an advanced system of utilizations, which can be effectively overseen on a tablet or better, their smart phones. The new technology poses a challenge to the previous generation to learn the ERP mode of operation and reporting, while maintaining the year long experience of business process to keep themselves much relevant to the organizations and exhibit their capacities to the organization.

At the end of an ERP training one should be able acquire and demonstrate the following skills in the implementation.

1. An understanding of Enterprise Resource Planning (ERP) and Electronic Business fundamentals.

2. Proficiency in and implementing Electronic Resource Planning (ERP) systems solutions.

3. Proficiency in Enterprise Resource Planning (ERP) technical functional requirements.

4. Proficiency in Enterprise Resource Planning (ERP) project planning.

5. Proficiency in Enterprise Resource Planning (ERP) project coordination.

6. Proficiency in finalizing Enterprise Resource Planning (ERP) customer business function requirements.

7. Competence in communications with Enterprise Resource Planning (ERP) users.

8. Proficiency in business and management processes.

9. Perform general organizational computing workplace competencies.

Demonstrate business communication skills and professional development skills.

The modern world has been appeared to be substantially demanding on the continuous improvements and users are given the abilities to keep up the new technology modules and skills improvements of themselves.

\section{CONCLUSION}

With the development of competitive world in the last decade the sustenance of the organization is highly associated with the use of technology, which requires adequate training for skill development for reaping the benefits of the investment made and provide good quality of service to the customers.

\section{REFERENCES}

1. Bhamangol, B. N. (2011). Enterprise Resource Planning (ERP) System In Higher Education: A Literature Review. International Journal of Management Research and Development, 1(1), 01-07.

2. Mohamed, S., \& McLaren, T. S. (2009). Probing the Gaps between ERP Education and ERP Implementation Success Factors, 1, 7.

3. Joseph, G., \& George, A. (n.d.). ERP, Learning Communities, and Curriculum Integration, 13, 8 .

4. Motwani J, Subramanian R, Gopalakrishna P. Critical factors for successful ERP implementation: Exploratory findings from four case studies. Comput Ind. 2005;56(6):529-433.

5. Dezdar S, Ainin S. The influence of organizational factors on successful ERP implementation. Manag Decis. 2011;49(6):911-926.

6. Venkatesh V. "One-Size-Does-Not-Fit-All": Teaching MBA Students Different ERP Implementation Strategies. J Inf Syst Educ. 2004;19(2):141-146.

7. Lee H, Chen KL. Teaching Enterprise Resource Planning ( ERP ) Systems in the Supply Chain Management Course. Commun IIMA. 2006;6(3):77-86.

8. Brandon-Jones A, Piercy N, Slack N. Bringing teaching to life : exploring innovative approaches to operations management education. Int J Oper Prod Manag. 2012;32(12):1369-1374.

9. Léger P. Using a simulation game approach to teach ERP concepts. J Inf Syst Educ. 2006;17(4):441 - 447.

10. Paa L, Ates N. Critical success factors of e-learning scenarios for ERP end-user training. In: Innovation and Future of Enterprise Information Systems. Vol 4. Springer; 2013:87-100.

11. Klima C, Pfarr F, Winkelmann A, Klima C, Pfarr F, Winkelmann A. Interactive Technology and Smart Education ERP system environments in IS education : design and evaluation of a new course concept. Interact Technol Smart Educ. 2014;11(2):112-122.

12. Leyh C, Winkelmann A, Lu J. Exploring the diversity of ERP systems - An empirical insight into system usage in academia. In: AMCIS 2011 Proceedings - All Submissions. Detroit, USA; 2011. 